\title{
Scholars, Librarians, and the Future of Primary Records
} Phyllis Franklin

\begin{abstract}
A survey of Modern Language Association members and of representatives of other associations participating in the American Council of Learned Societies indicates that the vast majority of those surveyed see ongoing need for collections of primary records. Respondents note that neither photocopies nor digital records can satisfy the traditional needs of bibliographers, textual editors, and literary scholars; furthermore, renewed interest in the materiality of texts and the history of print promises to continue to influence scholars who study publications belonging to the print era. Scholars note an important disagreement about the nature of primary records.
\end{abstract}

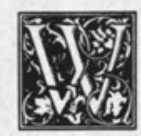

hat will scholars want from librarians in the years ahead as demands for access to information stored in increasingly varied formats accelerate? Because the issues implicit in this question are of great importance to modern language scholars, the opportunity to discuss them with you is particularly welcome, although it is also a little unnerving. Trying to reach across communities is rarely easy.

To prepare for the task, I followed a colleague's suggestion and consulted a book written by a former library director-Eldred Smith's The Librarian, the Scholar, and the Future of the Research $\mathrm{Li}$ brary. Unfortunately for my sense of selfconfidence, the book was not reassuring. Smith suggests that librarians are likely to view scholars as difficult-even ornery-people. According to Smith, scholars value convenience over reliability and depend primarily, in a wrongheaded way, on serendipity and what Smith describes as "alternative information-seeking methods"-informal networks. ${ }^{1}$ Smith writes, "[S]cholars utilize library collections remarkably little, the bibliographic apparatus even less, and librarians' reference services hardly at all."2 And when scholars do turn to libraries for what they are unable to find on their own, they can be quite disagreeable if what they want is not in. Actually, Smith is too polite to say scholars are disagreeable, but one senses restraint beneath his measured prose.

Although some tensions between scholars and librarians seem unavoidable, the positive connections these groups have enjoyed seem equally important and date back to the nineteenth century and the development of research libraries in this country. Consider, for example, George Ticknor, who, in 1819, became the first Smith Professor of French and Spanish Languages and Literature at Harvard University. After earning an undergraduate degree from Harvard, Ticknor went abroad to study at the University of Göttingen. There he learned to see libraries in a new way, and he brought this vision back with him. In 1812, while he was still in Germany, he wrote to a friend:

Phyllis Franklin is Executive Director of the Modern Language Association of America, 10 Astor Place, New York, New York 10003. A version of this article was presented as a talk at the American Library Association in 1992. 
... one very important and principal cause of the difference between [Harvard] and the [university] here is the different value we affix to a good library. ... In America we look on the Library at Cambridge as a wonder, and I am sure nobody ever had a more thorough veneration for it than I had; but it ... is ... half a century behind the libraries of Europe. .... [Even] worse than the absolute poverty of our collections of books is the relative inconsequence in which we keep them. We found new professorships and build new colleges in abundance, but we buy no books. ... We have not yet learnt that the Library is not only the first convenience of the University, ... it is the very first necessity, ... it is the life and spirit. ... ${ }^{3}$

\section{As published knowledge grew and library collections expanded, the organization of research libraries became correspondingly complex, and a managerial class of librarians emerged along with collection specialists.}

Books were so important to Ticknor that he insisted that the university allocate funds for them before he would accept the Smith professorship. ${ }^{4}$ The scholars who succeeded TicknorHenry Wadsworth Longfellow and James Russell Lowell-were no less energetic about adding to Harvard's collections. They were joined in this effort by Francis Child, who taught rhetoric and English literature and who served as a model for generations of scholars. ${ }^{5}$ In turn, these scholars pressed for better collections in their college and university libraries.

George Perkins Marsh, a modern language scholar who had struggled to be a scholar when no public collections of books existed, urged federal support of a national research library. As a member of the House of Representatives in 1844, Marsh opposed using the James Smithson bequest for "agricultural schools, popular lectures, chemical experiments, and other projects of immediate value to the common man." He pushed instead for "a big museum and a great national library for basic research and the diffusion of knowledge among scholars." Those who favored a museum and library won, although the book collection at the Smithsonian did not develop as Marsh hoped it would until it was moved to the Library of Congress in 1866.

Modern language scholars continue to depend on libraries, even though, as Smith notes, they have their own information-seeking methods, not all of which are idiosyncratic. For example, the MLA International Bibliography was conceptualized by scholars and librarians working together.

These instances of partnership between scholars and librarians serve as useful reminders that the ground between our communities has gradually shifted. As published knowledge grew and library collections expanded, the organization of research libraries became correspondingly complex, and a managerial class of librarians emerged along with collection specialists. Preoccupied by broad administrative questions-for instance, strategic planning and fund development - these librarians had concerns increasingly different from those of scholars, whose work remained largely unchanged, though they played a smaller role in helping to build library collections. Smith's book exemplifies some of these changes and makes clear why administrators of large libraries must care about efficiency and coherent national systems. The book also demonstrates how removed administrators' need for efficiency and systematic ordering can be from the research interests of humanities scholars.

Although Smith insists on an essential connection between scholars and librarians, his definition of a research library omits a key function of the research library for humanists. Smith writes:

Throughout their history, research librarians have functioned as the conservators of the record of scholarship. They have gathered and preserved the 
written, printed, and now electronically encoded information generated by the scholarly process as well as other information of immediate or potential value to research.?

What Smith misses is the role research libraries play in collecting and providing access not only to the "record of scholarship," but also to the primary records modern language scholars-and many historians, linguists, musicologists, and folklorists-require for their work. Just as scientists look to the natural world as the object of their investigations, so many if not most humanists look to libraries for the objects they study. Certainly, the research library has been the chief repository of the primary records that modern language scholars edit, analyze, and interpret. What the sky is to the astronomer, the rain forest is to the botanist, and the hurricane is to the meteorologist, the library is to scholars in the humanities. Perhaps that is why, as Smith himself notes, humanities collections are used more frequently than are social science or science collections. ${ }^{8}$

In addition to understating the importance of library collections for humanities scholars, Smith has a vision of the future ideal research library. The library he describes would be even further removed from the realities of scholarship in the humanities because collections would be entirely in electronic form, with print formats of documents produced on demand. 9

Not all visions of the future are so bleak for scholars who study literature written and published in the print era. In the realm of science fiction, "Star Trek," a popular television series set in the twenty-fourth century, makes a place for books in the otherwise hi-tech world of the Starship Enterprise. In "Star Trek: The Next Generation," Captain Picard reads books when he is off duty and enjoys Shakespeare in this format. On one occasion, the creators of the series even indicate a preference for the book over the computer. "Only from a book," we are told by a lawyer in one episode, can we "learn the intent of the men who wrote the law," because computer information is "homogenized, synthesized, [and] pasteurized." 10

Please do not misunderstand: humanities scholars are not Luddites. Since librarians already know that scholars can be ornery, they will not be surprised to learn that scholars expect to enjoy the advantages of both old and new technologies. Scholars respect the access photocopies and microfilms of the written and print records allow those who are unable to visit distant collections to study works of interest to them. They'recognize the need to save on microfilm at least an aspect of some of what was printed between 1850 and 1950. They welcome electronic databases of all kinds and electronic communication. Also they look forward to improvements in electronic scanning and to the creation of electronic texts of publications that appeared originally in print and publications of new works as well.

\section{SURVEY RESULTS}

In addition, modern language scholars and other humanists want ongoing access to primary records in their original form. Asurvey of members of the Modern Language Association (MLA) who served on MLA committees in 1991 and of colleagues in the American Council of Learned Societies is helpful on this point. In May 1992, 319 people were asked their views of the importance of rare books, archives, and the primary print record for scholars. Although the inquiry arrived at the end of the spring term, 169 people responded with letters, e-mail messages, and phone calls, which resulted in a response rate of 53 percent. The letters-many two to four pages long, some with comments on yellow Post-its added by colleagues, and others with copies of exemplary articles attached-testify to the value scholars place on primary records. Most respondents (95 percent) were MLA members, but a number of responses came from the administrative or elected officers of societies concerned with American studies, art history, biblical studies, folklore, history, linguistics, and musicology.

The results of the survey are clear. Only a handful of people- -1.7 percent- 
think copies will do, and another 3.5 percent believe our society cannot afford to maintain rare book collections and archives. But the vast majority -94.5 percent-assert the need for these collections.

They offer four general reasons. The majority -57 percent-affirm the importance of primary records for the traditional work done by bibliographers, textual editors, and literary critics. Shelley Fisher Fishkin of the University of Texas, Austin, whose studies of Mark Twain's Huckleberry Finn and other writings have been featured in the national press, is one of many who indicate their absolute dependence on the analysis of primary materials. Moreover, Fishkin is one of several respondents who report using rare book collections to teach graduate students. ${ }^{11}$

\section{Since librarians already know that scholars can be ornery, they will not be surprised to learn that scholars expect to enjoy the advantages of both old and new technologies.}

Along with emphasizing the need for primary records, 19 percent of the respondents question the stability and reliability of the technologies currently used to make copies. The experiences Peter Manning of the University of Southern California recounts are typical. He writes:

Sometimes the copying itself is imperfect: I have used the depository copies of the Dove Cottage Papers at Cornell University and encountered several puzzles that became substantially clearer when I saw the originals in Grasmere-though Wordsworth's manuscripts are never completely transparent. Even if copying is wellnigh perfect, however, the copy does not permit the comparison of inks to distinguish layers of revision, say, and the other resources that expert scholars now habitually employ. In the case of books a similar argument holds for the ability to detect minor variations in type, and depth of print, that may help to determine editions, impressions, and possible forgeries. Even to the less bibliographically specialized scholar, there can be no substitute for the physical impression of a book: the watermarking, quality, and weight of its paper, its binding, its internal formatting, in contrast to other books of its day, all contribute importantly to its effect, its meaning, as a social act. My own criticism has involved tracking Wordsworth's arrangement of successive editions of his poetry, work that would be much harder to accomplish and much more liable to overlook key features of the original impression the publications made were it not possible to handle the books themselves. ${ }^{12}$

Thirty-nine percent of the respondents cite as important scholars' renewed interest in the materiality of texts, and 28 percent point to the needs of those who study the history of the book. There is general agreement that primary records are an essential aspect of our culture and should be preserved in their original form, not, as Myra Jehlen of Rutgers University, New Brunswick, says, because we expect "future readers will read Keats as he wrote or as we read [him]; but so long as they have him in his original form, they can read him historically."13

Twenty-one percent of the respondents point to less tangible, aesthetic reasons for retaining rare book collections. Thomas M. Greene of Yale University writes:

I confess that as a grandchild of the Renaissance humanists, I have a particular slant on this issue. One can't exaggerate the intensity of the joy a humanist felt when he discovered the manuscript of a lost classical work in some monastery attic. The joy was produced first of all by the acquisition of an unknown text, but it was also produced by the physical presence of the artefact. The artefact, however badly copied, however moldered and dirty, was an object of veneration. And I must admit to vaguely similar feelings when I call for a great edition of the past in Beinecke library. I am not a 
religious believer, but I still recall the awe I felt when a copy of Erasmus's New Testament of 1516 was placed before me, that monumental version newly edited and translated in defiance of the church and all the authority of the Vulgate. This incredible triumph of the intellect (there were no Greek grammars available to Erasmus) and moral courage and patient tenacity, a triumph which rocked Europe, was there on the desk before me, with a frontispiece I never could have predicted. I wouldn't want to deprive future readers of that concrete object which deserves to be honored as an icon of human achievement and braveryboth Erasmus's achievement and all the others before and after him. ${ }^{14}$

\section{THE FUTURE OF PRIMARY RECORDS}

These letters, Smith's book, and other writings about preservation suggest that three issues may have confused discussions of the future of primary records. First, the model of microfilming brittle materials, which the Commission on Preservation and Access developed, seems to have inadvertently led some, perhaps many, people to assume that what is appropriate for brittle materials applies by extension to most or all of primary records. Economy and efficiency drive this assumption. Microfilming and the later conversion of microfilm to electronic formats will save storage costs and reduce the number of formats librarians must consider.

Although financial pressures are compelling, the solution to one problem is not necessarily the solution to another. The technology that gave us a century of brittle books is only a blip. It is a significant one to be sure, but only a part of the longer print era. As far as the respondents to this survey are concerned, when the choice is between losing the primary

- record and having a copy, microfilm must stand in place of print. When the primary record is sound, however, microfilm should be used only to supplement this record, whose integrity cannot be replaced by images.
A second confusing factor grows out of our society's current situation somewhere between the end of the print era and the beginning of the electronic era. Many of the proposals that prefer digital to primary records convey disdain for what is "old hat" and therefore no longer of interest to forward-looking people. The king is dead; long live the king.

That scholars' preoccupation with print should intensify while their use of electronic communication increases is intriguing. Major studies of the history of print have either just been completed (e.g., Roger Chartier's L'ordre des livres. Lecteurs, auteurs, bibliothèques en Europe entre XIVe et XVIIIe siècle) or are in progress (e.g., Ian Willison's history of the book before and after print). ${ }^{15}$ The historians engaged in these projects may be motivated by simple nostalgia, or they may feel some urgency to grasp and describe an age that is passing. Whatever the cause, the fact remains: interest in print has been growing among modern language scholars. At the request of MLA members, three meetings at the 1992 MLA convention focused on Chartier's work, and Chartier himself spoke at sessions that were very well attended.

\section{There is general agreement that primary records are an essential aspect of our culture and should be preserved in their original form.}

For the sake of argument, let us assume the print era will conclude in the year 2055, precisely six hundred years after it started. Imagine that the production of print publications begins to slow down early in the next century and stops finally-and even ceremoniously-in 2055. If we knew change would happen this way, how would our communities, including scholars and librarians, approach the question of preserving the primary print record, aware that the record then in existence is all that will ever exist? Would we not consider what people one or two centuries from now might want to know about our society 
and what scholars now and in the future will need to do their work? At this point, someone might wish to object. Won't many or most scholars be content witheven prefer-other formats? Won't strategically selected examples of the primary print record stored in rare-book collections or vaults or museums be sufficient for the relatively small number of scholars who might use them?

Only 12 percent of the survey respondents think saving a few copies of a book will satisfy the needs of modern language scholars. The majority argue that our society should maintain as complete a record of print as possible because such a record will continue to be essential to scholars who wish to study the print era. For example, focusing on the history of Frank Norris's novel McTeague, Joseph R. McElrath, Jr., of Florida State University notes the importance of collecting reprintings:

The physical work of 1899 , and its reprintings in 1900,1902, 1903, and 1914 contain physical features which become data for .... analyzing the entire publication history.... The way in which the printed sheets were folded and sewn, the kind of paper used, the observable wear of the plates as printing followed printing, the corrections of the plates before the latest printing, the binding, inscriptions on the fly leaves, and even the gilding of the ends of the leaves-all of these features are sources of important information for the analytical bibliographer and historian of the printing industry in the United States, who provide information to other kinds of historians and to critics. $^{16}$

Charles B. Harris of Illinois State University considers the same question from the perspective of a different novel. $\mathrm{He}$ writes:

In an interview several years ago, John Barth mused about the ontological status of a novel. "Where," he wondered, "does a novel exist?" It's not the kind of question one would ask about a painting; the Mona Lisa, for example, hangs on a wall in the Louvre. All copies of it are just that, copies, worth little when compared to the sole original that exists indisputably there in Paris. But where does Joyce's Ulysses exist? Is my paperback copy as authentic as the 1922 first edition? Probably not (it certainly isn't worth as much in hard cash), although that first edition, which contains an estimated four thousand errors, isn't exactly Joyce's novel, either. Is Joyce's manuscript of Ulysses the "real" thing, then, and if so, which version of that manuscript? Gabler's "synoptic" text was supposed to give us a definitive edition but resulted in a scandal instead. Soon, Norton will publish the Dublin edition of Ulysses. But even if Kidd is more successful than Gabler was in pleasing the critics and textual scholars, will we be able to call that version the "real" Ulysses-and, if so, which of the several thousand copies of the Dublin edition Random House prints will we be able to point to as the real Ulysses? Clearly, no book-at least since the invention of the printing press-can ever exist in [the] same way as the Mona Lisa exists. . . . Like some Vedic god, a book exists in all its incarnations simultaneously. ${ }^{17}$

While some respondents express concern about scholars' ability to study the history of books, others fear the field itself will change if originals are not retained. Myra Jehlen writes:

I am convinced that the disappearance of original texts would make the basic level of scholarship, the ground on which we all build, disappear. Without the possibility of looking at the actual materials we analyze, criticism, let alone historical studies, will be reduced to journalism. Literary scholarship will become an instrument for the distribution of literature-what bookreviewing is now; it will serve to introduce and mediate readings but will cease to be a primary analytical activity in its own right. And without the continual rethinking that this primary activity constitutes and generates, journalistic criticism itself will also lose its edge and come mostly to repeat established views. ... for the real work of 
preserving the cultural heritage, which is not to keep its dead but to keep it alive, it is essential to have the continuing presence of the original object. Not a transcription, not an abstract, but the thing itself. ${ }^{18}$

The letters cited above are useful not only because they reflect the ongoing interests of modern language scholars but also because they recall the complexities of establishing editions, which does not promise to become any simpler with electronic texts.

In time, of course, the publications of the electronic era will grow in size and importance, but an interest in print will surely be sustained. At least some, perhaps a good deal, of the literature published between 1455 and 2055 will continue to be studied and taught, and scholars will want to consult original materials. Just as we value records from the ancient and medieval worlds and regard original documents as providing the best evidence for scholarship, so future generations of scholars will regard primary records. Lawrence Lipking of Northwestern University suggests that:

the growing sophistication of electronic substitutes for print will dramatically magnify the importance of preserving books. As old habits of reading become archaic, the printed artifact will turn into invaluable historical evidence, a lifeline to the past. Then, even more than now, libraries will be needed to remind readers that other people once read in different ways. ${ }^{19}$

A third issue that has confused discussions of the future of primary records concerns a fundamental disagreement about the nature of these records. On one side are those who believe primary records contain information that is readily transportable from one format to another. On the other side are those who argue that the form and content of primary records cannot be separated without dramatically altering the evidence the record provides. In several key essays G. Thomas Tanselle has explored this question and related issues. He believes that the "electronic revolution" encouraged a view of print as information that is "independent" of its "container." Tanselle insists that for serious scholarly work, copies cannot replace originals; he argues that "all books should be regarded as rare books." 20

Tanselle is not alone. It is remarkable that 28 percent of the survey respondents support his position, which has not been in circulation for very long. Some respondents even describe attempts to deny the important relation between form and content as pernicious. Eric Rentschler of the University of California, Irvine, observes:

To copy a book is to render important parts of the text intangible and irretrievable, to transmute a concrete object into an imaginary signifier.

According to Christian Metz, film, or at least feature film, involves such a play with imaginary signifiers, the objects on the screen always simultaneously absent and yet present. (For this reason the cinematic apparatus is, one might argue, inherently protopostmodern.) In the case of rare books on microfilm (or other media), to make that signifier imaginary comes at the price of a great loss. A rare book perforce changes into a postmodern text, collected and encoded signs of which once we discard the original, there remains no material trace. In this way we quite literally lose "touch" with the past. ${ }^{21}$

In "Preserving the Literary Heritage," a report prepared by the Scholarly Advisory Committee on Modern Language and Literature of the Commission on Preservation and Access, committee chair J. Hillis Miller recognizes the validity of Tanselle's "eloquent defense for the need to have the actual books and papers for scholarly research." Although Miller and his colleagues on the Scholarly Committee on Modern Language and Literature accept the need for "microfilmed or digitalized preservation," they assume copies are necessary when originals cannot be saved. ${ }^{22}$

The disagreement about the nature of primary records is not a trivial one for scholars, who look with considerable interest to the materiality of texts for a 
better understanding of how these artifacts were produced, received, and used. A number of respondents commented on this renewed emphasis in literary study. James Grantham Turner of the University of California, Berkeley, writes:

We now look at the physical book in a new and sharper light, informed by the theoretical study of the way signs and texts operate.

Several of my current Ph.D. students have chosen to combine literary criticism with research into the material conditions of authorship, publication, and book distribution, breaking down the distinctions, or exploring the relations, between the verbal meaning of the text and the cultural history of its production. ... I insist that incoming graduate students, in their first course on problems and methods of literary interpretation, see a pre-modern printing press in action and handle original books and manuscripts; to turn the luxurious pages of a Pope quarto, carefully designed and supervised by the author himself, or to unfold a letter of Mary Wollstonecraft, teaches more than many hours at the microfilm machine. The study of the material text, not as a merely pretty "artifact" but as an intrinsic element in its meaning, has never been so vital. ${ }^{23}$ So important has the study of the material text become that some scholars report changing the way they carry out their research. Mary M. Gaylord of Harvard University says about her work with Spanish Golden Age poetry:

Whereas, a decade ago, I was reading more or less contentedly what works I could with the aid of modern scholarly editions, more recently I have returned to the physical experience even of already edited old books and have emerged not only with materials which earlier editors did not see fit to reproduce... but with a different understanding of the place of particular books in their cultures. ${ }^{24}$

Interest in the materiality of texts has affected the study of noncanonical as well as canonical writers. William L. Andrews of the University of Kansas says:
We have known for a long time that authors like Mark Twain took very seriously the way their writing would be packaged and sold, but we are much less knowledgeable about the economics of publishing and printing books for persons outside the sphere of privilege in which Mark Twain wrote. African American writers of the nineteenth century, for example, often had to publish their books at their own expense working hand-in-hand with local printers, the result of which was an artifact that often differs significantly from the mass-produced products of the larger commercial publishing houses. It would be a pity to limit or lose altogether our access to such artifacts as socioeconomic indicators while we are in the very process of trying to reproduce them for wider study as literary media. $^{25}$

Just as we value records from the ancient and medieval worlds and regard original documents as providing the best evidence for scholarship, so future generations of scholars will regard primary records.

Similarly, Ruth Bernard Yeazell of Yale University writes about her work with ladies' advice books and conduct manuals "of the sort that were printed and reprinted in abundance in England and America in the eighteenth and nineteenth centuries."

Though in one sense these would seem to be among the most expendable of material-certainly their literary value ... is slight-the recent development of interest in women's culture and writing, especially in that produced anonymously, ...." from below," . . . has made these texts of much more significance to scholarship than they might have been as little as a quarter century previously. And while what matters most, of course, is the words of advice that were so widely circulated, the size of such volumes, the quality of their paper, the 
form of their original binding (if known) all potentially testify to the classes to whom they were addressed and the uses to which they were expected to be put. To lose the artifacts in such cases would certainly be to lose some significant historical and cultural information. ${ }^{26}$

As far as archives are concerned, survey respondents commend our present arrangements of collections in a variety of institutional settings. In a telephone interview, John Stephens of the American Studies Association pointed out that much of the material that provided the basis for the social histories of the 1960s and 1970s was found in local historical societies, microfilms of local and state government records, and other scattered collections. Modern language scholars join historians in valuing the existence of local and regional archives that encourage the collection of materials that might not make their way into more distinguished settings but could someday be important to scholars.

The history of scholarship makes clear that what some generations of scholars ignore, other generations value. James Gardner of the American Historical Association confirms this point by calling attention to Laurel Thatcher Ulrich's treatment of a diary that a number of historians had examined over the years but had not used. Gardner says: "Ulrich ... saw in [the diary] something that the others did not and produced one of the most widely praised monographs in recent years." Ulrich's study, A Midwife's Tale: The Life of Martha Ballard, won four awards, including the Bancroft and Pulitzer prizes. Gardner adds that reviewers of the book have "emphasized how Ulrich's work has expanded our sense of [which] texts are valuable, de- monstrating that the non-elite, the ordinary people of the past, have left important primary sources that merit close reading and analysis, offering the potential of better understanding of both an individual life and the larger social and historical context in which that person lived." Gardner concludes by saying, "I doubt that Martha Ballard's diary would have made it on to any priority list in terms of national significance." 27

The survey results reported here are not likely to improve librarians' opinion of scholars, since the results do not provide solutions to the serious funding and space problems libraries confront. What scholars want librarians to do is maintain primary records in such a way that contemporary and future scholars who wish to study these artifacts will be able to do so. In addition, we all expect to go forward into the electronic era. There is one consolation. Modern language scholars stand ready to renew an old and honorable partnership with librarians. Together, we may be able to develop creative approaches to current problems and ensure the survival of primary records for future generations of scholars and librarians. To this end, the MLA Executive Council has appointed a committee to consider the future of primary records. The association hopes to encourage discussion of the issues our communities face.

As we move forward, we will keep in mind Robert Penn Warren's final statement in All the King's Men: "... soon now we shall go out of the house and go into the convulsion of the world, out of history into history and the awful responsibility of Time." ${ }^{28}$ MLA members believe, and perhaps you will agree, that our communities share responsibility for the records that others will someday need to tell-and retell-our history.

\section{REFERENCES AND NOTES}

1. Eldred Smith, The Librarian, the Scholar, and the Future of the Research Library (Westport, Conn.: Greenwood, 1990), 25.

2. Ibid., 21.

3. Orie William Long, Literary Pioneers: Early American Explorers of European Culture (Cambridge, Mass.: Harvard Univ. Pr., 1935), 12-13.

4. Ibid., 25-26. 
5. Phyllis Franklin, "English Studies: The World of Scholarship in 1883," PMLA 99 (May 1984): $360,366$.

6. David Lowenthal, George Perkins Marsh: Versatile Vermonter (New York: Columbia Univ. Pr., 1958), 82.

7. Smith, The Librarian, the Scholar, 7.

8. Ibid., 21.

9. Ibid., 72.

10. Shalom Staub of the American Folklore Society called these "Star Trek" incidents to my attention, and James Franklin verified the substance of the incidents.

11. Fishkin to author, June 5, 1992.

12. Manning to author, June $8,1992$.

13. Jehlen to author, June 4, 1992.

14. Greene to author, June 2, 1992.

15. Roger Chartier, L'ordre des livres. Lecteurs, auteurs, bibliothèques en Europe entre XIVe et XVILLe siècle, (Aix-en-Provence: Alinea, 1992).

16. McElrath, Jr., to author, June 3, 1992.

17. Harris to author, June 4, 1992.

18. Jehlen to author, June 4, 1992.

19. Lipking to author, June 9, 1992.

20. G. Thomas Tanselle, Libraries, Museums, and Reading (New York: Book Arts Pr., 1991), $25,20$.

21. Rentschler to author, June $12,1992$.

22. J. Hillis Miller, Preserving the Literary Heritage (Washington, D.C.: Commission on Preservation and Access, 1991), 2.

23. Turner to author, June $12,1992$.

24. Gaylord to author, June 20, 1992.

25. Andrews to author, June 5, 1992.

26. Yeazell to author, June 12, 1992.

27. Gardner to author, June 23, 1992.

28. Robert Penn Warren, All the King's Men (New York: Harcourt Brace Jovanovich, 1984), 438.

\section{IN FORTHCOMING ISSUES OF \\ COLLEGE \& RESEARCH LIBRARIES}

The Readability of Published, Accepted, and Rejected Papers Appearing in College \& Research Libraries

Cheryl Metoyer-Duran

Mature Librarians and the University Faculty: Factors Contributing to Librarians' Acceptance as Colleagues

Jean A. Major

Increasing Minority Representation in Academic Libraries: The Minority Librarian Intern Program at The Ohio State University

Jose Diaz and Kristina Starkus 